\title{
Food Self-Sufficiency Through Land Area Expansion (CGE Analysis in Indonesia)
}

\section{Ratya Anindita1 , Agnes Quartina Pudjiastuti², and Nur Baladina1}

${ }^{1}$ Department of Social and Economic, Faculty of Agriculture, University of Brawijaya, Veteran Street, Malang 65145

2Program Studies of Agribusiness, University of Tribhuwana Tunggadewi, Telagawarna Street, Malang 65144

\section{Abstract}

This study aimed to analyze the impact of land area expansion policy of paddy and corn crops towards food self-sufficiency in Indonesia. Analyses were performed by using CGE models based on the SAM data and Input Output Table of Indonesia in 2008. The result showed that the increase of land area of paddy and corn by $4-10 \%$, the paddy production will rise $36,21-87,93 \%$, while the corn production is relatively

Corresponding Author: Nur Baladina

baladina.fp@ub.ac.id baladinaa@gmail.com

Received: 28 July 2017

Accepted: 14 September 2017

Published: 23 November 2017

Publishing services provided by Knowledge $\mathrm{E}$

(c) Ratya Anindita et al. This article is distributed under the terms of the Creative

Commons Attribution License, which permits unrestricted use and redistribution provided that the original author and source are credited.

Selection and Peer-review under the responsibility of the ICSAFS Conference Committee. constant even going down to $0,55 \%$. If the land of paddy and corn increased by 4-10\%, it will decrease the export of almost all sectors in Indonesia, except the food and beverage industry whose increased $52-118,12 \%$, as well as fertilizer and pesticide industries whose are relatively constant. On the other hand, the land area expansion of paddy and corn 4-10\% will not affect the import of this commodity. Thus, it can be concluded that the land area expansion of paddy and corn crops have a positive impact on food self-sufficiency (rice and corn) in Indonesia.

Keywords: land area expansion; paddy and corn crops; food self-sufficiency; CGE models.

\section{Introduction}

Food policy analysis has become the focus of the experts since a long time ago, especially after the worldwide food crisis in 1973-1974 and a fears of food crisis in 1979-1980 will continue to happen [1]. The main role of food policy analysis is to design a national food program that connects micro and macro environmental issues, aiming for faster food growth. Four basic goals of national food policy are: (1) the efficiency of growth in agricultural sector, (2) the increase in the distribution of income through expanding new job vacancy, (3) the adequacy of nutrition for the entire society, and (4) ensuring adequate food security when harvest time fails, natural disasters or food supply and unstable world prices [2]. 
World food crisis is a serious threat to society in the world, including Indonesia. Indonesia's dependency on imported food is one cause of this situation. But agriculture development in Indonesia by using self-supporting system (swasembada) is a condition for continuity of nation's existance in addressing the threat of global food shortages [3]. Fertile land conversion, land and water degradation, climate change and environmental degradation, has been becoming a major constraint in the development of food self-sufficiency oriented in the future [4].

Provision of food, particularly rice, in sufficient quantities and at reasonable prices remains a top priority of national development. Besides being a staple food for more than $95 \%$ of the people of Indonesia, paddy has also provided employment for around 20 million households in the rural areas. In the period of 2000-2006, the population of Indonesia has increased at a growth rate of $1.36 \%$ per year while rice consumption was $137 \mathrm{~kg}$ per capita. Assuming a declining population growth rate of $0.03 \%$ per year, the consumption of rice in 2015 and 2025 respectively projected at 34.12 million tonnes and 37.43 million tonnes. The total population in the second period were estimated respectively around 249 million and 273.2 million people [5]. If the assumption is not met, Indonesia should be able to provide food in larger quantities. If not, then the food dependency on imports will be greater.

To fulfil food demand especially rice in the country, the government can increase the production of food crops (rice) by using multiple scenarios, one of which is food selfsufficiency. Self-sufficiency in food (rice) can be achieved by expanding land based on the following facts [6]. National paddy production in 2012 totalled 69.05 million tons of dry unhusked paddies or experiencing an increase of 3.29 million tonnes (5\%) compared to 2011 . The increase of production occurred in Java as much a $2.12 \mathrm{mil}-$ lion tons and 1.17 million tons outside Java. Increaseing in production occurs due to increasing of harvested area as much as 239.80 thousand hectares $(1.82 \%)$ and the increase of productivity by 1.56 quintal/hectare (3.13\%). Food (rice) self-sufficiency can be maintained until 2025 when the rate of land conversion can be inhibited to about 75,000 ha/year and the addition of wetland through new paddy fields around 100,000 ha/year [7].

Related to previous explanation, the effort to expand the area of cropland through the opening of new land recently has become very important to support the selfsufficiency of rice, given the need for food crop production that continues to increase while the conversion of land each year occur in area broad enough [8]. With the opening of new land then areas available for farming will increase, so that the production of rice and maize will increase and the availability of food for $95 \%$ of Indonesian society will also increase. The contribution of rice and corn sector's to gross domestic product will also be larger. If the domestic demand for rice and corn are met, then self-sufficiency can be achieved. In addition, food self-sufficiency scenario also would 
reduce Indonesia's dependency on imported rice and corn which means it will also improve the trade balance and the exchange rate. This means that Indonesia will be able to finance the import of commodities that do not have a competitive advantage. Therefore, this study aimed to analyze the impact of land expansion policy especially for rice and corn to food self-sufficiency.

Preliminary research that has been done [9] using data from SAM 2005 has produced findings that marketing efficiency improvement has positive impact on sectoral economic performance. A research was conducted using CGE models to evaluate the impact of the efficiency improvement of marketing of agricultural products to food security and household welfare in Indonesia with the data base tables of SAM 2008 and Input Output table 2008. The findings are marketing efficiency improvement having positive impact on food security and household welfare [10].

Results of previous studies that have been described indicate that the results of policy evaluation using a model of general equilibrium analysis will be an essential ingredient for developing policies and for the development of science, considering that during this time, the majority of policy evaluation using partial equilibrium analysis model. Therefore, it is important to assess whether the new policy of printing wetland recommended by the government will support the achievement of food selfsufficiency and have positive impact on sectoral economic performance.

\subsection{CGE (Computable General Equilibrium) Model}

In economic system, changes in the balance of a market have impact on other economic sectors and activities through the input-output relationship. General equilibrium occurs when the supply and demand in each market in the system is in a state of equilibrium simultaneously. The disturbance causing imbalance in a partially market will be immediately followed by an adjustment in the relevant market and the subsequent adjustment process occurs in other markets (simultaneous adjustment) which brought the economy to the new balance. The mechanism of achieving a balance on all types of goods in all applicable markets for producers and consumers is called general equilibrium analysis [11].

The general balance will occur when the economy is in a state of perfect competition and there is no increasing return to scale [12]. The economy that has no competitive state will not have a point in general equilibrium. In its development, General equilibrium model formulated by Arrow and Debreu is known as CGE models.

CGE model is a comprehensive approach that encapsulates multimarket models and uses the balance of market as its analysis basic element [13]. A CGE model illustrates economic actors and behaviour which directs the various markets into a general balance. CGE model formulation includes the linkages between economic actors, i.e. the 
company or industry, households, investors, governments, importers, exporters and between different commodity markets. The entire market will be in a state of balance and has a specific structure to achieve a balance when there are shocks in one market [14].

With comprehensive system of equations, CGE model has the advantage of revealing impact on production, consumption, trade, investment and overall spatial interaction of a policy or shock. This model has been applied to simulate the socio-economic impacts of a scenario. First, foreign shocks is such as changes of terms of trade (i.e. the increase of imported oil price or drop of main exported commodity prices in a country). Second, changing in economic policy is such as taxes and subsidies in the trade. Third, changing in social structure of domestic economy, such as changing in agricultural technology, the redistribution of assets and human capital formation $[15,16]$.

According Yeah et al. [17], CGE model is not only used in the model of international trade but also in the model of development planning, finance, environment, resource management, as well as changes in economic and market transitions [17]. The cornerstone of microeconomic theory used include elasticity parameters and inputoutput data, so that the CGE model is the experimental analysis tool for analyzing the economic changes, including the expansion of land area.

\section{Methodology}

CGE models are the best choice if the policy evaluation will have significant effects to the whole economy. Moreover, CGE models are the best option if the research question involves analyzing the static/dynamic, direct/indirect and short/long term effects caused by a shock. Thus, because of its nature, CGE analysis performs well when evaluating, among others, fiscal policy, trade policy, climate change shocks and shocks in international prices, especially agriculture policy that is: self sufficiency through land expansion.

CGE model developed in this study is how to introduce the expansion of the area of land into a model of the economy so that the policy affects the achievement of food self-sufficiency in Indonesia. To achieve these objectives static CGE model developed reported in Reference $[15,18,19]$ was used assuming constant return to scale. This model is more appropriate to look at the effects of policy [20-22].

The data used was secondary data obtained on Statistics Social Accounting Matrix (SAM) Indonesia and Input Output (I0) of Indonesia in 2008, while some of the coefficients/other parameters such as the elasticity of Armington, elasticity factor of primary production, and the elasticity of substitution is obtained from various sources in previous studies. SAM is an open framework of comprehensive economic data that represent the economy of a country [23]. While Reference [24] states that SAM is 
written in table form a square matrix with an agent name as the name row and column names. In addition, the model in this study was also constructed using MPSGE approach. By using GAM/PSGE, calibration can be performed simultaneously [13].

CGE model used in this study is a static CGE. Data of SAM 2008 and I-0 table 2008 to be the basis for aggregating and disaggregating sectors to be 10 sectors (6 sectors of food crops and 4 other sectors) and 8 households. The first step taken was to arrange basic matrix (85×85), eliminate the negative elements in the SAM Indonesia, further validation (balancing) of SAM, SAM mapping, compiling data models and static CGE model are solved by GAMS/MPSGE, then do simulation. To refine the analysis, performed several simulations policies, namely: (a) expansion of paddy land and corn amounting to $4 \%$, (b) expansion of paddy land and corn by $5 \%$, and (c) expansion of paddy land and corn by $10 \%$. Selection of simulation figure of $4 \%$ and $5 \%$ based on the rationalization that refers to the current conditions, self-sufficiency in rice and corn in Indonesia will be achieved if land for both agricultural commodities is expanded 4$5 \%$. While the simulation figure of $10 \%$ was chosen to find out what happens when self-sufficiency in food (rice and corn) has been reached.

\section{Results and Discussion}

Land expansion of crops to achieve rice and corn self-sufficiency will have an impact on the economic performance of sectors that exist in Indonesia, not only limited to the economic performance of rice and corn sectors. The analysis showed that the land expansion of corn and rice, in general, has a positive impact on the achievement of food self-sufficiency that can be seen from the quantity indicators of domestic output, exports and imports, as presented below.

\subsection{Impact on national production performance}

Table 1 shows that the policy of paddy and corn land expansion by $4-10 \%$ has a positive impact on the performance of national production in the sectors of rice, beans, tubers, food and beverage industry, and other industries, except for sectors of national corn, other crops, and fertilizer and pesticide industry. If paddy and corn land is increased by $4 \%$, rice production will rise $36.21 \%$, while corn production will fall by $0.55 \%$ and production of other food crops do not increase constantly. Furthermore, paddy and corn land expansion by 5-10\%, will increase rice production to 75 to $87.93 \%$, while corn production is not increased and the production of other food crops will be down to $0.19 \%$. The empirical evidence indicates that there is trade off between land for rice farming, corn, and other crops. 
TABLE 1: The impact of land expansion for paddy and corn on the national production.

\begin{tabular}{|c|c|c|c|c|c|}
\hline \multirow[t]{2}{*}{ No. } & \multirow[t]{2}{*}{ Sector } & \multirow[t]{2}{*}{$\begin{array}{l}\text { Baseline } \\
\text { (Trillion IDR) }\end{array}$} & \multicolumn{3}{|c|}{$\begin{array}{c}\text { Percentage Change in Production due to } \\
\text { the Land Area Expansion of Paddy and } \\
\text { Corn }\end{array}$} \\
\hline & & & $4 \%$ & $5 \%$ & $10 \%$ \\
\hline 1 & Paddy & 116 & 36,21 & 75,00 & 87,93 \\
\hline 2 & Nuts & 65 & 16,92 & 32,31 & 36,92 \\
\hline 3 & Corn & 183 & $-0,55$ & 0,00 & 0,00 \\
\hline 4 & Tubers & 72 & 0,00 & 1,39 & 1,39 \\
\hline 5 & Other food crops & 534 & 0,00 & $-0,19$ & $-0,19$ \\
\hline 6 & Other crop farming & 1.734 & $-0,12$ & 0,69 & 0,81 \\
\hline 7 & $\begin{array}{l}\text { Food and beverage } \\
\text { industry }\end{array}$ & 5.805 & 46,77 & 138,43 & 154,40 \\
\hline 8 & $\begin{array}{l}\text { Industrial fertilizers and } \\
\text { pesticides }\end{array}$ & 48 & $-4,17$ & $-2,08$ & $-2,08$ \\
\hline 9 & Other industry & 5.277 & 4,38 & 10,21 & 11,20 \\
\hline 10 & Trade, hotel and restaurant & 2.560 & $-0,94$ & $-0,59$ & $-0,51$ \\
\hline 11 & Service & 6.480 & $-0,37$ & $-0,32$ & $-0,34$ \\
\hline
\end{tabular}

The increase of national rice production at 36.21 to $87.93 \%$ due to the expansion of the land area is expected to support the achievement of rice self-sufficiency program launched by the government of Indonesia in 2018. But it is important to understand that efforts to increase food production using the same land area as rice, corn, and some other food crops can not be done only through the expansion of planting areas, but effort to open new agricultural land or conducting land revitalization which is quite large in amount.

But the increase of national production of paddy, beans, tubers, and other agricultural crops are not supported by an increase of national production of industrial fertilizers and pesticides. If paddy and corn land is expanded by $4-10 \%$, the industrial production of fertilizers and pesticides will drop from 2.08 to $4.17 \%$. This condition happens due to the reducing use of chemical fertilizers and pesticides at farm level.

While increasing of performance of national production of food and beverage industry ( 46.77 to $154.40 \%$ ) and other industrial sectors (from 4.38 to $11.20 \%$ ) are suspected as the outcomes from the increasing production of paddy, nuts, tubers and other crops, which in turn will also increase the national production of food and beverage industry as downstream industry of fresh agricultural products, including land expansion of paddy and corn that has a positive impact on the performance of other sectors related to backward linkage and forward linkage with paddy and corn as corps. 


\subsection{Impact on export performance}

The simulation results presented in Table 2 indicates that the policy of paddy and corn land expansion by $4-10 \%$ will reduce export performance of almost all sectors in Indonesia, except paddy sectors and fertilizers and pesticides industry that has constantly unchanged export quantity, as well as the food and beverage industry which has increasing in term of export quantity by 52.90 to $118.12 \%$.

Based on existing data in SNSE Indonesia in 2008, Indonesia does not export rice because domestic production has not been able to fulfil ddomestic demand. In other words, Indonesia, at this time, still import rice. Rice exports will be carried out after rice self-sufficiency is achieved; i.e if dry harvested grain production has reached 84 million tons. Production is targeted to be achieved by 2019. Based on information from various sources, it is estimated that rice and corn self-sufficiency will be achieved if both agricultural commodities land is expanded to $4-5 \%$. If self-sufficiency of rice and corn has been reached, Indonesia will be able to export rice. However, simulation results by land expansion of paddy and corn up to 10\% did not indicate this phenomenon, because a constant quantity of rice export did not change from baseline of o trillion IDR. The causes are: first, the SNSE database in 2008, which is used in this analysis, did not contain rice exports; and secondly, over estimate of substitution elasticity between land, capital and labor as production factors.

While constant export quantity of fertilizer and pesticide industries sector does not change from baseline of 2 trillion IDR, presumably because the sector is still not able to fulfil domestic needs. Moreover, the national production of fertilizers and pesticides industries has declined from 2.08 to $4.17 \%$ from baseline of 48 trillion IDR when land expansion of paddy and corn by $4-10 \%$ happened, so that production of fertilizers and pesticides industries has been sold out in domestic market without the need to be exported.

If the land of corn and paddy are expanded by $4-10 \%$, the export performance of food and beverage industries will increase from 52.90 to $118.12 \%$ from the baseline export value of 2,274 trillion IDR. The increasing of export performance of food and beverage industries allegedly happens because of the increasing of food and beverage production by 46.77 to $154.40 \%$ due to land expansion policy of corn and paddy as much as $4-10 \%$, so most of production of food and beverage industries are not sold out in domestic market and must be exported overseas.

Declining exports will affect a country's trade balance. However, total decline of export performance from various sectors as presented in Table 2 as a result of paddy and corn land expansion by $4-10 \%$, the value is still lower than the increasing in exports of food and beverage industry. In addition, other important component of the trade balance is also being imported. Declining of exports is followed by decreasing 
TABLE 2: The impact of paddy and corn land expansion of to export.

\begin{tabular}{|c|c|c|c|c|c|}
\hline \multirow[t]{2}{*}{ No. } & \multirow[t]{2}{*}{ Sector } & \multirow[t]{2}{*}{$\begin{array}{c}\text { Baseline } \\
\text { (Trillion IDR) }\end{array}$} & \multicolumn{3}{|c|}{$\begin{array}{l}\text { Percentage Change in Exports due to the } \\
\text { Land Area Expansion of Paddy and Corn }\end{array}$} \\
\hline & & & $4 \%$ & $5 \%$ & $10 \%$ \\
\hline 1 & Paddy & 0 & 0 & 0 & 0 \\
\hline 2 & Nuts & 0,94347 & $-0,01$ & $-0,01$ & $-0,01$ \\
\hline 3 & Corn & 0,72558 & $-0,66$ & $-1,33$ & $-1,51$ \\
\hline 4 & Tubers & 0,20673 & $-0,45$ & $-0,86$ & $-0,97$ \\
\hline 5 & Other food crops & 0,86074 & $-1,98$ & $-4,91$ & $-5,68$ \\
\hline 6 & Other crop farming & 65 & $-16,92$ & $-36,92$ & $-41,54$ \\
\hline 7 & $\begin{array}{l}\text { Food and beverage } \\
\text { industry }\end{array}$ & 2.274 & 52,90 & 107,52 & 118,12 \\
\hline 8 & $\begin{array}{l}\text { Industrial fertilizers and } \\
\text { pesticides }\end{array}$ & 2 & 0,00 & 0,00 & 0,00 \\
\hline 9 & Other industry & 2.293 & $-12,04$ & $-26,21$ & $-28,74$ \\
\hline 10 & Trade, hotel and restaurant & 77 & $-11,69$ & $-23,38$ & $-25,97$ \\
\hline 11 & Service & 7 & $-71,43$ & $-91,71$ & $-93,01$ \\
\hline
\end{tabular}

in imports where the declining of imports is greater than the declining of imports will produce trade balance remained positive.

\subsection{Impact on import performance}

Impact of corn and paddy land expansion to import of all sectors in Indonesia is presented in Table 3. Policy of paddy and corn land expansion by $4-10 \%$ has an effect on the increasing of quantity of imports in almost all sectors, except for imports of rice and corn sectors that is constantly unchanged. Import of rice sector were carried out constantly at baseline of 5 trillion IDR and imports of corn sector were constantly carried out at baseline of 4 trillion IDR, which is indicating national production of paddy and corn that have not been able to fulfil domestic demand.

Import performance of other sectors besides rice and corn showed a significant increase. In fact, the greater the percentage of land expansion, the higher imports of other sectors in the economy are. Sectors experienced highest increase in imports are other crops, food and beverage industries, and other agricultural crops. It should be underlined that the increase of imports would significantly affect the status of Indonesia's trade balance, deficit or surplus in the trade balance.

The higher import of sectors in economy is in line with the greater percentage of land expansion of paddy and corn, it is thought to occur because of the trade off between the production of paddy and corn with other crops and agricultural plants, as a result of the agricultural commodities cultivation on same land. While food and beverage 
TABLE 3: Impact of paddy and corn land expansion to import.

\begin{tabular}{|c|c|c|c|c|c|}
\hline \multirow[t]{2}{*}{ No. } & \multirow[t]{2}{*}{ Sector } & \multirow[t]{2}{*}{$\begin{array}{l}\text { Baseline } \\
\text { (Trillion IDR) }\end{array}$} & \multicolumn{3}{|c|}{$\begin{array}{l}\text { Percentage Change in Imports due to the } \\
\text { Land Area Expansion of Paddy and Corn }\end{array}$} \\
\hline & & & $4 \%$ & $5 \%$ & $10 \%$ \\
\hline 1 & Paddy & 5 & 0 & 0 & 0 \\
\hline 2 & Nuts & 13 & 15,38 & 30,77 & 38,46 \\
\hline 3 & Corn & 4 & 0,00 & 0,00 & 0,00 \\
\hline 4 & Tubers & 0,8938 & 1,94 & 3,54 & 3,95 \\
\hline 5 & Other food crops & 27 & 44,44 & 88,89 & 100,00 \\
\hline 6 & Other crop farming & 38 & 31,58 & 52,63 & 55,26 \\
\hline 7 & $\begin{array}{l}\text { Food and beverage } \\
\text { industry }\end{array}$ & 306 & 34,97 & 62,09 & 67,97 \\
\hline 8 & $\begin{array}{l}\text { Industrial fertilizers and } \\
\text { pesticides }\end{array}$ & 70 & 15,71 & 30,00 & 34,29 \\
\hline 9 & Other industry & 2.930 & 18,77 & 39,80 & 43,86 \\
\hline 10 & Trade, hotel and restaurant & 183 & 10,93 & 18,58 & 20,22 \\
\hline 11 & Service & 975 & 18,67 & 34,05 & 37,33 \\
\hline
\end{tabular}

industries is experiencing increase in imports which is allegedly due to production other agricultural commodities used as declining raw materials.

Beside to fulfil domestic needs, the increasing imports of sectors in economy can also be caused due to low domestic competitiveness. It is characterized by domestic commodity prices that are relatively higher than similar imported commodity prices, or the quality of domestic commodities that are relatively lower than similar imported commodities quality. However, domestic commodity prices that are higher in long term can also encourage domestic producers to increase their output so that the quantity of imports will drop [25].

\section{Conclusions and Recommendations}

Land area expansion policies of paddy and corn have a positive impact on food selfsufficiency in Indonesia. If the land area of paddy and corn increased by $4-10 \%$, it will increase the national production of almost all sectors in Indonesia, except for corn, other crops, also fertilizers and pesticides industries. Empirical evidence indicates that there is a trade-off between the land for paddy farming, corn, and other crops. If land of corn and paddy is increased by $4 \%$, the rice production will rise to $36.21 \%$, while corn production will constant and continuesly fall by $0.55 \%$ and so does, production of other food crops that will be fall to $0.19 \%$.

If the land area of paddy and corn increased by $4-10 \%$, it will decrease the export of almost all sectors in Indonesia, except the food and beverage industry which increased 
52.90-118.12\%, as well as fertilizer and pesticide industries and rice sectors whose are relatively constant. If the land area of paddy and corn increased by $4-10 \%$, it will not affect the import of this commodity.

To reduce the negative impact of the trade-off from land expansion of paddy and corn, government policy intervention is required. These interventions are expected to increase national production of rice and corn to support rice and corn self-sufficiency program, but it also can increase the production of other food crops sector and other sectors involved in the economy. Examples of policies that can be taken are: (1) expansion of rice and corn planting area that is more focused on opening new agricultural land or revitalizedation abandoned land/marginal area; (2) In addition, land expansion needs to be optimized through intensification, increasing cropping intensity, innovation development of cultivation and post-harvest technology, improved watershed management, soil and water conservation, and protection against conversion of agricultural land, abandonment and degradation.

\section{Acknowledgements}

Thanks for Directorate of Research and Community Service, General Directorate Education and Student Affairs, Ministry of Research, Technology and Higher Education of Indonesia, and Rector of University of Brawijaya who was willing to fund the research accordance with Addendum of Assignment Agreement Letter in the Program Implementation of Directorate of Research and Community Service number: 007 / Add / SP2H/PL/DIT.LITABMAS/V/2015 dated May 12, 2015. Hopefully this research can enrich the science and into recommendations for the government's policy of agricultural development-oriented food self-sufficiency.

\section{References}

[1] Timmer, C.P. 2008. International Best Practice in Food Policy: Reflections on Food Policy Analysis. Asian Journal of Agriculture and Development, Vol. 7, No. 1.

[2] Timmer, C.P., Falcon, W.P. and Pearson, S.R. 1983. Food Policy Analysis. Baltimore: Johns Hopkins University Press.

[3] Apriyantono, A. 2009. Kebijakan dan Strategi Pengembangan Lahan Pertanian untuk Keberlanjutan Ketahanan Pangan dan Pengembangan Bioenergi. Prosiding Semiloka Nasional Strategi Penanganan Krisis Sumber Daya Lahan untuk Mendukung Kedaulatan Pangan dan Energi: 9-12. Fakultas Pertanian, IPB, Bogor.

[4] Mulyani, Anny, S Ritung and Irsal Las. 2011. Potensi dan Ketersediaan Sumber Daya Lahan untuk Mendukung Ketahanan Pangan. Jurnal Litbang Pertanion, 30(2). Balai Besar Penelitian dan Pengembangan Sumberdaya Lahan Pertanian. Bogor. 
[5] Pusat Penelitian dan Pengembangan Tanaman Pangan, 2014. Peningkatan Produksi Padi Menuju 2020. Badan Penelitian dan Pengembangan Tanaman Pangan. http://pangan.litbang.pertanian.go.id/files/padizozo.rar. Diakses tanggal 3 September 2015.

[6] Badan Pusat Statistik. 2012a. Luas Lahan Menurut Penggunaan Tahun 2012. Jakarta: BPS.

[7] Agus, F. and A. Mulyani. 2006. Judicious use of land resources for sustaining Indonesian rice self-sufficiency in Rice Industry, Culture and Environment. Proceedings of International Rice Conference. Book 1. Indonesian Agency for Agricultural Research and Development, Jakarta.

[8] Direktorat Jenderal Prasarana dan Sarana Pertanian. 2013. Perluasan Areal Sawah Baru Menjadi Salah Satu Solusi untuk Meningkatkan Volume Produksi Beras dalam Negeri. http://psp.pertanian.go.id/index.php/page/publikasi/41. Diakses tanggal 3 September 2015.

[9] Anindita, Ratya. 2010. Dampak Efisiensi Pemasaran Hasil Pertanian Terhadap Perekonomian Indonesia. Pidato Pengukuhan Jabatan Guru Besar dalam Bidang Ilmu Pemasaran Hasil Pertanian pada Fakultas Pertanian Universitas Brawijaya. BAPSI UB.

[10] Anindita, Ratya, Nur Baladina and Budi Setiawan. 2103. Effect of Marketing Efficiency Improvement in Indonesia. Russian Journal of Agricultural and SocioEconomic Sciences, 7(19):13-21.

[11] Hulu, E. 1997. Tipologi Model Keseimbangan Umum. Jakarta: Universitas Indonesia.

[12] Arrow, K.J. and Debreu, G. 1954. "Existence of an Equilibrium for a Competitive Economy," Econometrica. Vol. 22: 265-290.

[13] Markusen, J R. 2005. Introduction to GAMS for Economic Euilibriums Problems. University of Colorado, Boulder, version July 4, 2005.

[14] Oktaviani, R. 2001. Dampak Perubahan Kebijakan Fiskal terhadap Kinerja Ekonomi Makro dan Sektoral. Bisnis dan Ekonomi Politik 4(4):33-45.

[15] Soudolet, E. and A. de Janvry. 1995. Quantitave Development Policy Analysis. The Jhon Hopkins University Press.

[16] Robinson, Sherman and Shantayanan Devarajan. 2013. The Contribution of CGE Modeling to Policy Formulation in Developing Countries in Handbook of Computable General Equilibrium Modeling, 1st Edition Vol. 1A editor by Peter B Dixon \& Dale W Jorgenson. North Holland. Elsevier.

[17] Yeah, K. L, John F. Yanagida, Hiroshi Yamauchi. 1994. Evaluation of External Market Effect and Government Intervention in Malaysia's Agricultural Sector: A Computable General Equilibrium Framework. Agricultural Economics, 11: 237-256. 
[18] Lofgren, H., R. L. Harris, S. Robinson. 2002. A Standard Computable General Equilibrium (CGE) Model in GAMS. Microcomputers in Policy Research International Food Policy Research Institute. Washington DC.

[19] Pudjiastuti, A.Q.; Anindita, R.; Hanani, N dan Kaluge, D. 2013. Effects of Sugar Price Increase In Indonesia. Studia UBB, Oeconomica, Volume 58, Issue 1, 2013.

[20] De Melo, J. 1988. Computable General Equilibrium Models for Trade Policy Analysis in Developing Countries: a Survey Journal of Policy Modeling 10(3): 469-503.

[21] Decaluwe, B. and A. Martem. 1988. CGE Modeling and Developing Economia A Concise Empirical Survey of 73 Applications to 26 Countries. Journal of Policy Modeling 10(3): 469-503.

[22] Moran, C. and P. Serra. 1993. Trade Return under Regional Integration: Policy Simulations using a GCE and for Guatemala. 40(1) 103-132. Journal of Development Economics 40(1):103-132.

[23] Breisinger, C., M. Thomas and J. Thurlow. 2009. Social Accounting Matrices and Multiplier Analysis: An Introduction with Exercises. Food Security in Practice Series. Washington D.C.: The International Food Policy Research Institute (IFPRI).

[24] Hosoe, N., K. Gasawa and H. Hashimoto. 2010. Textbook of Computable General Equilibrium Modelling: Programming and Simulations. New York: Palgrave Macmillan.

[25] Kohls, R. L. and J. N. Uhl. 2001. Marketing of Agricultural Products, 9th Edition. Prentice-Hall. 